\title{
Serena Biondo \\ Chapter 5 \\ Narrative Sources of the Great Debate
}

The 'Great Debate' at Bsam yas (called variously the 'Lha sa Debate,' the 'Council of Lha sa' or the 'Council of Tibet') has attracted much scholarly attention from the mid-twentieth century up to the present. ${ }^{1}$ The aim of this chapter is not to give a definitive reading of the key issue of the debate, i.e. the contest between the gradual and sudden paths to enlightenment. Rather, it is to examine how the narrative of the debate in the $D b a^{\prime}$ 'bzhed was assembled and the function this narrative played in this version of the text.

1 The secondary literature up to 2000 is summarised in Matthew T. Kapstein, The Tibetan Assimilation of Buddhism: Conversion, Contestation and Memory (Oxford: University Press, 2000), 220, n. 71. The key sources are listed here for ready reference: Paul Demiéville, $L e$ concile de Lhasa; une controverse sur le quiétisme entre bouddhistes de l'Inde et de la Chine au VIII. siècle de l'ère chrétienne (Paris: Impr. nationale de France, 1952); Giuseppe Tucci, Minor Buddhist Texts. Part II, First Bhāvanākrama of Kamalaśila. Sanskrit and Tibetan texts with introduction and English summary (Rome: IsMEO, 1958); Yoshiro Imaeda, "Documents Tibétains de Touen-Houang Concernant le Concile du Tibet," Journal Asiatique 263 (1975): 125-46; Alex Wayman, "Doctrinal Disputes and the Debate of bSam yas," Central Asiatic Journal 21, no. 2 (1977): 139-44; Luis O. Gómez, “The Direct and the Gradual Approaches of Zen Master Mahayana: Fragments of the Teachings of Mo-ho-yen," in Studies in Ch'an and Hua-yen, ed. Robert M. Gimello \& Peter N. Gregory (Honolulu: University of Hawaii Press, 1983), 71-167; Flemming Faber, "A Tibetan Dunhuang Treatise on Simultaneous Enlightenment: The dMyigs su myed pa tshul gcig pa’i gzhung,” Acta Orientalia 46 (1985): 47-77; Flemming Faber, "The Council of Tibet According to the sBa bzhed,” Acta Orientalia XLVII (1986): 33-61; Leonard van der Kuijp, “On the Sources for Sa skya Pandita's Notes on the Bsam yas Debate," Journal of the International Association of Buddhist Studies 9, no. 2 (1986): 147-53; David Seyfort Ruegg, Buddha-Nature, Mind and the Problem of Gradualism in a Comparative Perspective. On the Transmission of Buddhism in India and Tibet (London: SOAS, 1989); David Seyford Ruegg "On the Tibetan Historiography and Doxography of the Great Debate of bSam yas," in Tibetan Studies: Proceedings of the $5^{\text {th }}$ Seminar of the International Association for Tibetan Studies, ed. Shōren Ihara and Zuihō Yamaguchi (Narita-shi, Chiba-Ken, Japan: Naritasan Shinshoji, 1992), vol. 1, 237-44; Sven Bretfeld, “The 'Great Debate' of bSam yas: Construction and Deconstruction of a Tibetan Buddhist Myth,” Asiatische Studien 58, no.1 (2004): 15-56. Tom J.F. Tillemans, "Yogic Perception, Meditation, and Enlightenment," in A Companion of Buddhist Philosophy, ed. Steven M. Emmanuel (West Sussex: Wiley Blackwell, 2013), 290-306. Further philosophical issues concerning the debate were also discussed in 2014 at the Congress of the International Association of Buddhist Studies in a panel called “The Bsam yas Debate: Challenges and Responses.” The papers of this panel have been published in the Journal of the International Association of Buddhist Studies 39 (2016): 339-518.
While discussing the sources that were used to build the account of the debate in the Dba' bzhed, I will digress to explain the identity and stance of Sang shi, one of the disputants. The Dba' bzhed sheds a new light on Sang shi's words and his philosophical alignment. This prompts a reconsideration of later versions of the Testimony of $B a$ and also of previous scholars' interpretations of Sang shi's identity and position. These problems led me to add a further section called "Further Complexities: Sang shi in the Testimony of $B a$." This moves away from the narrative of the $D b a$, bzhed proper but provides useful information regarding the later Testimony of $B a$ tradition on this important figure.

The dispute between those who believed in an instantaneous approach to enlightenment and those who advocated a gradual path that led step-by-step to realisation belongs to the main narrative of the Testimony of $B a$ in all its known versions. As the text declares in its opening lines, the core of the story concerns the first appearance and establishment of Buddhism in Tibet. Such a narrative could not but describe the construction of the Bsam yas temple and the institution of the Buddhist samgha. Therefore, the kind of dharma and the monastic traditions that were adopted-as well as the reasons for their adoptionwere unavoidable subjects of discussion. However, it is unclear when the debate came to be part of this narrative. The patchwork nature of this section of the narrative makes it improbable that the earliest compilers of the Testimony had a ready-made description of the debate on which they could draw. Despite the philosophical nature of the discussion, the debate has a strong political dimension, which suggests that compilers and redactors of the Testimony created an account that was inflected by their own positions, interests and agendas. The $D b a^{\prime}$ bzhed compilers must have arranged the sources at their disposal-in addition to what they knew-in a way that was conducive to their point of view. That the debate was put together on the basis of different records is reasonably evident. The 'bricks' used to form the structure are clear, yet their arrangement reveals a number of 'weak points' in the fabric suggesting that the compilers were not completely free in their choice of material and that some of their sources might have contained unwelcome information. ${ }^{2}$

2 In the field of Buddhist studies, one of the first to speak of authorship as the ability to assemble new structures from old building 
The following pages seek to identify as many building blocks as possible to see how and why they were brought together and to explain, moreover, the different understanding of the parts that have emerged over time. In doing this, I will follow the sequence of debate events. Table 5.1 below aims to identify the main sections of the debate and it provides a guide to the discussion that follows. The events that lead to the debate are numbered 1 to 6 in the table; for the sake of convenience I refer to these as the 'introduction to the debate.'

Table 5.1: Key episodes of the debate

1 Heshang Moheyan ${ }^{3}$ arrives in Tibet 18v:5

2 Conflict between Moheyan's followers and Śāntarakṣi- 18v:6 ta's followers

3 The king summons Ye shes dbang po back from his $\quad$ 19r:2 retreat

4 Ye shes dbang po recites Śāntarakṣita's prophecy 18v:7

5 Kamalaśīla is summoned to Tibet 19v:3

6 Moheyan and his disciples prepare for the debate. They $19 \mathrm{v}: 3$ study the Prajñāpāramitā sūtra in one hundred thousand verses and reject the Samdhinirmocana sūtra.

7 The king opens the debate stating the reasons why the 20r:2 debate was hold

8 Moheyan speaks (3 ${ }^{\text {rd }}$ Bhāvanākrama + unidentified 20v:1 passage)

9 Kamalaśīla speaks ( $3^{\text {rd }}$ Bhāvanākrama) 20v:6

10 The king opens the discussion to the followers of the $22 \mathrm{r}: 5$ two factions

11 Sang shi speaks (historical/doctrinal remarks + sum- 22r:6 mary of the Six Perfections + remarks on the instantaneous and gradual approaches)

12 Dpal dbyangs speaks (remarks on the instantaneous 22v:6 and gradual approaches + Samdhinirmocana sūtra + a final attack to the instantaneous approach)

13 The king proclaims the gradualists to be victorious

$24 \mathrm{v}: 2$

blocks was Jonathan Silk, "Establishing/ Interpreting/ Translating: Is It Just That Easy?" Journal of the International Association of Buddhist Studies 36-37, nos. 1-2, (2015): 205-26. Several publications have appeared on the subject of intertextuality and authorship in the past few years. Among these, see the articles under the heading of " $\mathrm{Au}$ thors and Editors in the Literary Traditions of Asian Buddhism" in the Journal of the International Association of Buddhist Studies, 2015 and under "Reuse and Intertextuality in the Context of Buddhist Texts" in Buddhist Studies Review, 2016. In this short chapter, I shall sidestep theoretical questions on the identity and nature of authorship, and simply call those who assembled the various texts of the Testimony of $B a$ 'compilers.'

3 The spelling used for the Chinese master in the Dba' bzhed is "Hwa shang Mahayana," often shortened as "Mahayana” or simply "Hwa shang." Here I call him Heshang Moheyan which corresponds to the Chinese 和尚摩訶衍. When capitalised 'Heshang' refers to Moheyan.

\section{Introduction to the Debate}

The narrative of the debate starts after the account of the construction of Bsam yas and settlements for the sponsorship of the monks; this results in Ye shes dbang po's meditative retreat in Lho brag. The text states that most monks at that time became followers of a Chinese master named Heshang Moheyan. Moheyan-according to the Testimony-teaches a doctrine based on absence of dualistic thought and the instantaneous attainment of nirvāna. This doctrinal position disagrees with that of the Indian side, put forward by Sañntarakșita, and endorsed by the king, which asserts that nirvāna can be achieved only through gradual stages. As friction between these two parties increases, the followers of Moheyan cause disturbances by self-harming and threatening violence against those following the gradual path.

The king then calls Ye shes dbang po-who has gone into retreat-to solve the conflict. The latter, though unwilling to interrupt his meditation, eventually agrees to return. Once he arrives, he reprimands the king for not being able to sort out the matter on his own. Ye shes dbang po then recites the last words Śāntarakșita pronounced before his death. These announce that during the last five hundred years of the dharma disagreements were bound to arise among the Buddhist sangha. At that time Sāntarakṣita's disciple Kamalaśilla should be summoned to correct the monks who have gone astray. Sāntarakșita's words therefore link the well-known theory of the last five hundred years of the Buddha dharma on earth-believed to have been first pronounced by the Buddha himself-to the present disagreement between Indian and Chinese monks in Tibet. ${ }^{4}$ In this way, the text prepares the stage for the debate and confers on it a higher significance.

While Kamalaśîla is being fetched from Nepal, Ye shes dbang po explains the gradualist approach to the king who in turn proclaims Ye shes dbang po his spiritual teacher. The followers of the instantaneous path lock themselves in the Bsam gtan gling to study the Prajñāpāramitā in a hundred thousand verses in preparation

4 The best study to date on the development of the theory of the last five hundred years of the doctrine is Jan Nattier, Once Upon a Future Time: Studies in a Buddhist Prophecy of Decline (Berkeley, Calif: Asian Humanities Press, 1992). It would be difficult, however, to understand which source the $D b a$ ' bzhed used for Śāntarakșita's prophecy as there is no specific detail in the story to link it to a particular account concerning the last five hundred years of the dharma. A discussion concerning the five-hundred years prophecy in this context can be found in Chapter 6 in this volume. 
for the debate. The text explicitly says they set aside the Saminhinirmocanasūtra.

\section{The Debate}

The debate starts with the instantaneous and gradualist parties entering the temple; the king seating in the centre, the instantaneous party on the right and the gradualists on the left. The main followers of Heshang Moheyan and Kamalaśîla are introduced. Heshang's disciples are: Jo mo Byang chub, Sru Yang dag and the monk Lang Ka. Kamalaśîla’s disciples are Dba' Dpal dbyangs, Dba’ Rad na and "a few ordained monks" (dge slong mi mang ba zhig). ${ }^{5}$ A garland is presented to Heshang and Kamalaśîla. The king opens the discussion by explaining that the debate is held because disagreement has arisen between the followers of the Indian master and those of the Chinese master.

The first to speak is Heshang Moheyan. His speech spans from folio 20v, line 2 to folio 20v, line 5. Flemming Faber first recognised that the Heshang's words come from Kamalaśîla's third Bhāvanākrama. ${ }^{6}$ In fact, the passage from folio 20v line 2 to folio 20v, line 4 corresponds quite closely to the third Bhāvanākrama's passage stretching from 122:1 to 122:2. ${ }^{7}$ This section of the Bhāvanākrama discusses the wrong views professed by "someone" (gang $z$ hig) ${ }^{8}$ but it is uncertain whether Kamalaśila wrote it after the debate-and therefore gives us Kamalaśila's understanding of Moheyan's view-or if the compiler of the $\mathrm{Dba}$ ' bzhed put these words in Moheyan's mouth. The final passage of Moheyan's speech in the Dba' bzhed (20v:420v:5) is not attested in Kamalaśîla's work. This runs as follows: "For the intelligent, purified in previous births, virtuous and sinful deeds obscure [the mind] equally, just as the sky is obscured equally by black and white clouds. Those who do not do anything, do not conceptualise and do not focus, they instantaneously attain the level similar to the tenth stage [on the path of enlightenment]." The source of this passage is not known but these words are

5 DBA' 2000, 20r:1.

6 Faber "Council," 49. Faber refers to the Sba bzhed-s he had at his disposal, but as the two quotations are very similar his remarks also apply to the $D b a^{\prime}$ bzhed; see also Pasang Wangdu and Hildegard Diemberger, $d B a$ ' bzhed: the Royal Narrative Concerning the Bringing of the Buddha's Doctrine to Tibet (Vienna: Verlag der Österreichischen Akademie der Wissenschaften, 2000), 81, n. 313.

7 Bsgom pa'i rim pa, in Bstan 'gyur (Sde dge). Delhi: Sde dge par khang, 1982-1985, vol. 110.

8 Bsgom pa'i rim pa 122:1.

9 The translations in this chapter follow that by Gonkatsang and Willis in Part Two of this volume. found in both SBA 1961.1-2 and SBA 1982.1-3 and Dpa' bo Gtsugs lag phreng ba's Chos byung mkhas pa'i dga' ston (SBA 1980). ${ }^{10}$

There are minor differences between the version of the Bhāvanākrama that is found nowadays in the $B k a$ ' 'gyur and the version quoted in the Dba' bzhed. Thus, it could be surmised that the compiler of the latter text was in possession of a different copy of Bhāvanākrama than the one now available. However, it is noteworthy that, among the different versions found in the Testimony, the Dba' bzhed is closest to the Bhāvanākrama as presently preserved. It would be difficult to decide whether the last sentences of Heshang Moheyan (cited in the previous paragraph) appeared in an earlier version of the Bhāvanākrama-now lost but available to the compiler of the Dba' bzhed-or whether the compiler, having copied the relevant section of the Bhāvanākrama, decided to supplement it by adding words attributed to Heshang that he had heard or read. The latter hypothesis (i.e. that the compiler added material) gains extra weight when we consider that some Tibetan texts connected with Moheyan and his instantaneous approach were created by assembling passages from the Bhāvanākrama and words attributed to him found in Dunhuang manuscripts. ${ }^{11}$ However, I was unable to locate this passage in the Dunhuang materials, so the source remains unknown for the present.

10 This sentence is subject to a slight variation in SBA 1961.1-2, SBA 1982.1-3 and SBA 1980. While DBA' 2000, 20v:4 records that the clouds obscure the sky (nam mkha'), SBA 1961.1-2, 58.6, SBA 1982.1-3, 68.18 and SBA 1980, 383:2, record that the clouds obscure the sun (nyi $\mathrm{ma}$ ). As the later versions of the Testimony of $B a$ had a larger diffusion than the $D b a$ ' bzhed ever did, almost all the subsequent texts quoting this passage have the sun rather than the sky. A couple of exceptions are Bu ston's chos 'byung and Padma dkar po's Phyag rgya chen po'i man ngag gi bshad sbyar rgyal ba'i gan mdzod in Gsung 'bum Padma Dkar po. Darjeeling: Kargyud sungrab nyamso khang, 1973-1974. vol. 21, 331: 5). The structure of this sentence in the Bu ston chos 'byung and the Dba' bzhed is too different to suppose any relationship between the two, but Pad ma dkar po's sentence is very close to the $D b a^{\prime}$ bzhed's. However, as the rest of the debate does not match-and sun and sky are easily interchangeable-it is impossible to say if Padma dkar po had access to a version of the Testimony of $\mathrm{Ba}$ closer to the $D b a$ ' bzhed or it was more simply Padma dkar po's emendation.

11 For example, the Cig car 'jug pa rnam par mi rtog pa'i sgom don. On this text, see Luis O. Gómez, "Indian Materials on the Doctrine of Sudden Enlightenment," in Early Ch'an in China and Tibet, ed. Whalen Lai and Lewis R. Lancaster (Berkeley, CA: Asian Humanities Press, 1983), 393-434; Faber, “A Tibetan Dunhuang Treatise”; Joel Gruber, “The Sudden and Gradual Sūtric (and Tantric?) Approaches of the Rim gyis 'jug pa'i bsgom don and Cig car 'jug pa rnam par mi rtog pa’i bsgom don," Journal of the International Association of Buddhist Studies 39 (2016): 405-27. 
After the Chinese monk has made his statement, Kamalaśīla replies (20v:6-22r:5). This section corresponds to 122:3-125:2 of the third Bhāvanākrama and consists of Kamalaśila's answer to the wrong views of an unnamed opponent. ${ }^{12}$ Thus, except for the last passage of Heshang's speech, the compiler of the Dba' bzhed copied the whole section from the Bhāvanākrama, i.e. the wrong thesis and the correct thesis. Kamalaśila's speech and the Bhāvanākrama run closely parallel, although two quotations from the Gayaśîrșa and the Tathāgathaguhya sūtra reported in the Bhāvanākrama do not appear in the Dba' bzhed. ${ }^{13}$ Again, the question remains whether the $D b a^{\prime}$ bzhed was quoting an earlier version of the Bhāvanākrama (which did not contain these quotations) or, more simply, the compiler decided not to include the quotations. If the first case, it would suggest that Kamalaśilla, or some later compilers of the Bhāvanākrama, added the quotations at a later phase after finding scriptural corroboration for these arguments. If the second, the Dba' bzhed compiler either wished to shorten Kamalaśila's speech (which is disproportionally long compared with that of Moheyan) or preferred not to make Kamalaśila explicitly quote other texts during his speech.

12 Bsgom pa`i rim pa, 122:1. A few folios below, Kamalaśila says that those who claim that nirvāna is obtained without practising generosity and so forth are accepting the view of the Ājīvaka but whether he is referring to some Indian Buddhist scholar who propounded this Ājīvaka view or to the Chinese monk is unclear. Bsgom pa'i rim pa 127:5: yang dge ba la sogs pa'i las ci yang mi bya'o zhes zer ba de ni de skad smra bas las zad nas grol bar 'gyur ro zhes mu stegs can kun tu tshol ba'i smra ba khas blangs par 'gyur ro. As Ruegg notices the term "Ājivivaka" in the Tibetan version of the Bhāvanākrama is translated "mu stegs can kun tu tshol ba"; Ruegg, Buddha-Nature, 142, n. 271. 13 A few sentences are also missing in Kamalaśila's speech in the Dba' bzhed, mainly where he references the two quotations. The quotations are found in the Bhāvanākrama, 122:5-7. Both the translations of the Gayaśîrșa and the Tathāgataguhyasūtra are found in the $B k a$, 'gyur. According to the colophons of these two texts, the Gayaśirșa and the Tathāgataguhyasūtra were translated during the first diffusion by the famous translator and compiler of the Mahāryutpatti, Ye shes sde. The colophon of the Gayaśirș̣a also gives the name of the Indian master Surendrabodhi, who also was involved in the compilation of the Mahāryutpatti and whose duty was to correct the translations made by Ye shes sde and the other Tibetan translators. The passage of the Gayasisirșa quoted in the Bhāvanākrama is to be found in Ga yā mgo'i ri'i mdo: Bka' 'gyur (Sde dge: Sde dge par khang chen mo, 1733), vol. 49, 575:7 and 576:1 (CA, 288v:7 and 289r:1). The very short passage quoted by Kamalaśîla from the Tathāgataguhyasūtra finds an approximate parallel in De bzhin gshegs pa'i gsang ba bsam gyis mi khyab pa bstan pa'i mdo: Bka' 'gyur (Sde dge par khang chen mo, 1733), vol. 39, 207:5-6 (KA, 103r:5-6).

\section{Changing Speakers and Changing Positions}

When the representative of the two factions end their presentations, the king opens up the debate to include the leading disciples of the instantaneous and gradual approach. Only two people speak, but the names of those two people change depending on which version of the Testimony of Ba we read. In DBA' 2000 and SBA 1961.1-2, these are Sang shi and Dpal dbyangs, while in SBA 1982.1-3 and Gtsug lag phreng ba's SBA 1980, Dpal dbyangs and Ye shes dbang po speak. It should be noted that neither Sang shi nor Ye shes dbang po appear among the disciples who followed the two masters at the beginning of the debate, either in the Dba' bzhed or in SBA 1961.1-2 and SBA 1982.1-3. ${ }^{14}$ The only exception is Gtsug lag phreng ba's SBA 1980, which replaces the usual Dba' Ratna or Sba Ratna with Ye shes dbang po. ${ }^{15}$ Table 5.2 below first compares the names of Moheyan's and Kamalaśila's followers in the different exemplars of the Testimony of $B a$, and then compares them with the names of the people who eventually spoke at the debate.

Sang shi appears, though there is no mention of him in the lists of the two masters' disciples. ${ }^{16} \mathrm{He}$ commences his talk by giving a short recapitulation of the Six Perfections (pāramitā)-dāna, śila, kṣānti, vīrya, dhyāna and prajñ $\bar{a}-$ after which he comments on the formation of new schools after the death of the Buddha.

Sang shi's intervention is somewhat peculiar. Earlier scholars, who had only later versions of the Testimony to guide them, agreed on the basis of his speech that Sang shi or Dpal dbyangs (depending on the version) was on the side of the gradualists. However, there is enough evidence to suppose that originally Sang shi's argument was either on the side of Moheyan or that it represented a more moderate and conciliatory group. Several points suggest this. For example, we know from the introduction to the debate that the proponents of the instantaneous party spent two months reading the Shes rab 'bum in preparation. Therefore, we would expect them

14 SBA 1961.1-2, 57.2-5; SBA 1982.1-3, 67.8-12.

15 SBA 1980, 381:6-7.

16 One could argue that the compiler of the text confused Dba' Rad na with 'Ba' Sang shi, as at the end of the Testimony we find Rad na called 'Ba' Rad na. However, this does not seem to be the case, since Rad na's clan name is only spelled 'Ba' instead of Dba' in the Zas gtad appendix (25v:6). There is no confusion with regard to Dba' Ratna's clan name in the main text of the $D b a^{\prime}$ 'bzhed. For a discussion on the names see below. 
Table 5.2: List of Heshang's and Kamalaśilla's disciples as given in the introduction to the debate and list of the people who intervened in the debate after Moheyan and Kamalaśīla's speeches

\begin{tabular}{|c|c|c|c|c|}
\hline & DBA' 2000 & SBA 1961.1-2 & SBA 1982.1-3 & SBA 1980 \\
\hline Moheyan's disciples & $\begin{array}{l}\text { Jo mo Byang chub } \\
\text { Sru Yang dag } \\
\text { Lang ka }\end{array}$ & $\begin{array}{l}\text { Jo mo Byang chub rje } \\
\text { Sru Yang dag } \\
\text { Lang ka }\end{array}$ & $\begin{array}{l}\text { Jo mo Byang chub } \\
\text { Bsru Yang dag } \\
\text { Lang+ga }\end{array}$ & $\begin{array}{l}\text { Jo mo Byang chub } \\
\text { Sru Yangdag } \\
\text { Lang+ka }\end{array}$ \\
\hline Kamalaśîla's disciples & $\begin{array}{l}\text { Dba' Dpal dbyangs } \\
\text { Dba' Rad na } \\
\text { Unnamed ordained monks }\end{array}$ & $\begin{array}{l}\text { Dbal dbyangs } \\
\text { Bai to tsa na } \\
\text { Rat+na }\end{array}$ & $\begin{array}{l}\text { Sba Dpal dbyangs } \\
\text { Bai ro tsa na } \\
\text { Sba Rat+na }\end{array}$ & $\begin{array}{l}\text { Rba Dpal dbyangs } \\
\text { Bai ro tsa na } \\
\text { Ye shes dbang po }\end{array}$ \\
\hline Speakers at the debate & $\begin{array}{l}\text { Sang shi } \\
\text { Dpal dbyangs }\end{array}$ & $\begin{array}{l}\text { Sang shi } \\
\text { Dpal dbyangs }\end{array}$ & $\begin{array}{l}\text { Dpal dbyangs } \\
\text { Ye shes dbang po }\end{array}$ & $\begin{array}{l}\text { Dpal dbyangs } \\
\text { Ye shes dbang po }\end{array}$ \\
\hline
\end{tabular}

to use aspects of this text to substantiate their point of view.

The way Sang shi presents the Prajñāpāramitā echoes what we know of Heshang Moheyan's teachings: Sang shi's explanation of the Six Perfections is that each of the Perfections is in its highest form when the practitioner is able to go beyond the dichotomy of that Perfection and its reverse. Later texts, including SBA 1961.1-2 and SBA 1982.1-3 slightly modify the text so that Sang shi seems to claim that what he said about the Perfections represents the wrong view of the Heshang, and not his own. This is clear if we look at the first few words of Sang shi's speech. The Dba' bzhed simply starts with "rgya'i cig car ’jug cing rim gyis sbyor ba ..." ("The Chinese instantaneous entrance and the application through stages ...”). In SBA 1961.1-2 Sang shi is still the speaker, but the beginning of his speech slightly changes: "rgya'i ltar na cig car 'jug cing rims gyis sbyongs mchis ..." ("According to the Chinese there are the simultaneous entrance and the application through stages ..."). SBA 1982.1-3 puts these words into the mouth of Dpal dbyangs and the following speech of Dpal dbyangs is then pronounced by Ye shes dbang po. To make even clearer that Sang shi and Dpal dbyangs are on the gradualist side, SBA 1982.1-3 begins with khyed rgya'i bzhed pa ("You, holders of the Chinese [position]"). ${ }^{17} \mathrm{Bu}$

17 The beginning of Sang shi's talk affects the reading of the whole speech, so it is worthwhile to look at it a bit more closely. SBA 1982.13, 70.9-10 says: khyed rgya'i bzhed pa ltar na/ cig char 'jug cing rim gyis sbyong mchi na/ pha rol tu phyin pa 'dzin pa ma mchis pa'i slad du ... . After this sentence, the explanation of the Six Perfections begins. As the first words directly address the Heshang's party, it is clear that "because you do not even understand the Prajñāpāramitā" (pha rol tu phyin pa 'dzin pa ma mchis pa'i slad du) refers to them. The result is that the following explanation of the parramitā-s reports Moheyan's mistaken understanding of the Six Perfections. The Dba' bzhed (22r:6) only reports: rgya'i cig car 'jug cing rim gyis sbyor ba mchi [ba]/ pha rol du phyin pa drug kyang 'dzin pa ma mchis pa'i phyir ... . If we were ston's account seems to be closer to SBA 1961.1-2 because, although it puts this speech in the mouth of Dpal dbyangs, like SBA 1982.1-3, it starts with rgya'i ltar. ${ }^{18}$ Yet, the following passage concerning the Six Perfections is worded differently from all the Testimony of $\mathrm{Ba}$ versions. ${ }^{19}$ SBA 1980 follows SBA 1982.1-3 (or Bu ston) in making Dpal dbyangs

reading presupposing that, as Moheyan spoke first at the debate, so his disciple was the first to speak after the king opened the discussion to the others, we could easily read this sentence "because you [gradualists] do not even understand the Prajñāpa aramitā" and then the natural explanation of the real, correct meaning of the Perfections, i. e. Moheyan's view explained by one of his disciples. The reasons why this second option is more plausible are discussed below but it is clear from this that, if Sang shi was reporting the Heshang's wrong reading of the pāramitā-s, he should have at least ended his speech by giving the right reading or a remark of some sort. Instead, after this lengthy exposition (of theoretically wrong views) he drops the subject without any criticism and picks up another theme.

18 Chos kyi 'byung gnas gsung rab rin po che'i gter mdzod in Gsung 'bum/ rin chen grub, ed. Lokesh Chandra (New Delhi: Zhol bka' 'gyur par khang, 1965-1971) vol. 24, 889:4.

$19 \mathrm{Bu}$ ston's account is different from the others, and slightly closer to Gtsug lag phreng ba's narration. For example, where the Testimony of Ba tradition says: "if [you] do not even understand the Six Perfections ...” Both Bu ston and Gtsug lag phreng ba supplement the sentence by adding that, according to the Chinese, the Six Perfections should be understood as their reverse (... pha rol tu phyin pa drug mi mthun phyogs las gdags par gsung te). Then Gtsug lag phreng ba goes on to give the shortened explanation of the Six Perfections that we find in the Sba bzhed-s. Bu ston, on the other hand, explains his statement further by taking as an example the Perfection of generosity and saying that this concept holds true also for the other Perfections rather than discussing the other five Perfections individually. According to him: "Highest Charity is thus viewed only as the absence of greediness. The fact of abstaining from every kind of appropriation thus represents the Highest Transcendental Charity" $\mathrm{Bu}$ ston Rin chen grub, History of Buddhism (Chos-hbyung,) trans. Eugéne Obermiller (Heidelberg: In kommission bei O. Harrassowitz, 1931), 194. 
speak instead of Sang shi. ${ }^{20}$ It also includes Ye shes dbang po in the list of Kamalaśila's disciples. ${ }^{21}$ Besides distancing the speaker from the Chinese side, SBA 1961.1-2, SBA 1982.1-3 and SBA 1980, by naming the Chinese at the beginning of the speech, are able to attribute to them the wrong understanding of the pāramitā-s that follows. Compared to the $D b a$ ' bzhed, the later versions give a truncated explanation of the Perfections so that the Chinese reading of the päramitā-s becomes a mere negation of the Perfection in question. Thus, generosity is simply giving up craving; forbearance is the mere lack of wrath; diligence is the lack of laziness and so forth. This is not the case with the $D b a$ ' bzhed, where the explanation of each Perfection is elaborated on, and it is said that that the best form of generosity, forbearance etc., is the one that transcends that Perfection and its reverse. At the end, Sang shi (or Dpal dbyangs) does not attempt, even briefly, to correct the Chinese wrong understanding of the Perfections, but goes on explaining how the schools formed after the death of the Buddha. Thus, although SBA 1961.1-2, SBA 1982.1-3 and SBA 1980 are similar in wording to the Dba' bzhed, their meaning changes.

In his closing remarks, Sang shi seems to propose that both the approaches - gradual and instantaneous- are genuine methods to reaching enlightenment. By comparing the emergence of the three Mādhyamika schools with that of the sudden and gradual approaches, he appears to grant orthodoxy to both. The reason that is given for the appearance of all these schools is that the death of the Buddha left his disciples without anyone who could clarify their doubts and keep the samgha united. As already noted, the purport of this claim is not very different from what we find in Sāntarakșita's prophecy about the degeneration of the dharma during the last five hundred years. Yet here, Sang shi presents the issue in a more positive light. What Śāntarakșita announces as a quarrel among Buddhists-in which one side is irrevocably wrong and the other right-Sang shi explains as the formation of different schools, all tending to the right end.

Finally, Sang shi's assertion (and in other versions that of Dpal dbyangs) that the "the goal is one" for both gradualist and instantaneous schools is afterwards contradicted by Dpal dbyangs (and in other versions Ye shes dbang po) who asserts most clearly that "the instantaneous entrance and the application through gradual stages,

20 SBA 1980, 384:6.

21 SBA 1980, 381:6-7 (see Table 5.2 above). Bu ston does not name the disciples at all. Instead he reports a list of text titles that Heshang Moheyan wrote at the time when he was preparing for the debate (Chos kyi 'byung gnas, 887:5-6). these two should be spoken of distinctly" and a few lines later: "the two paths, gradualist and instantaneous, are totally different." The words of Dpal dbyangs, when read after Sang shi's, as they appear in the text, sound like an attack on Sang shi's position. This would not make sense, of course, if Sang shi was putting forward a gradualist position.

In terms of general structure, Sang shi's intervention fits more appropriately if it stands on the Chinese side: the king opens the debate to the teachers; the instantaneous side speaks; the gradualist side responds; the king then opens the debate to the disciples; the instantaneous side speaks; and the gradualist side responds. The fact that Sang shi does not appear among the disciples of either party introduced at the beginning of the debate is somewhat peculiar. It may suggest either that the writer was not inclined to class Sang shi on the Heshang's side, or that Sang shi was above factionalism. ${ }^{22}$ On the contrary, Dpal dbyangs-who speaks after Sang shi-is introduced as Kamalaśîla’s disciple.

\section{Further complexities: Sang Shi in the Testimony of $\mathrm{Ba}$}

The $D b a^{\prime}$ bzhed does not provide any information on Sang shi's background. He appears first as one of the ministers who are sent to investigate Sañntarakșita's intentions and then he becomes one of the most prominent delegates in the China expedition. SBA 1961.1-2, SBA 1982.1-3 and SBA 1980, however, give an interesting history of Sang shi's origin. Here he is presented as the son of a Chinese envoy named 'Ba' De' $u$ who is in Tibet during the reign of Khri Srong lde btsan's father, Khri Lde gtsug btsan. 'Ba' De'u leaves his son in Tibet as companion to the young prince. Sang shi is thus able to speak both Chinese and Tibetan and for this reason is sent to China to look for the dharma. In SBA 1961.1-2 and SBA 1982.1-3 Sang shi goes on two expeditions to China, rather than just one. ${ }^{23}$ The first is during the reign of Khri Lde gtsug btsan and the second-which happens at the time of Khri Srong lde

22 This matter is discussed in Chapter 2 of this volume, in Willis and Gonkatsang's remarks on folio 22r.

23 This section comes in the very first pages of the later Testimony of Ba versions. SBA 1961.1-2, 4.11; SBA 1982.1-3, 5.4. Several scholars questioned Sang shi's identity, see Jeffrey L. Broughton, "Early Ch'an Schools in Tibet," in Studies in Ch'an and Hua-yen, ed. Richard M. Gimello \& Peter N. Gregory (Honolulu: University of Hawaii Press, 1983), 54; Kapstein, Tibetan Assimilation, 71. 
btsan-corresponds with the expedition narrated in the $D b a^{\prime}$ bzhed. We do not know whether the compiler of the $D b a$ ' bzhed knew the story of Sang shi's origins, or if it was a later addition in SBA 1961.1-2 and SBA 1982.1-3 taken from a later source. Nonetheless, Sang shi-who travels to China and receives the instructions of revered Kim-does not seem to be right person to argue against the Chinese Heshang.

As discussed in Chapter 2 of this volume, the narration of Śantarakșita's first arrival in Tibet differs between RBA 2011.1 and the Dba' bzhed. RBA 2011.1 does not list Sang shi as one of the ministers who the king sends to interrogate the Indian master, while the $D b a$ ' bzhed emphasises the fact that three ministers are sent. The BL fragment also contains this story but the section of the manuscript that should include the names of the ministers is missing. Sam van Schaik and Kazushi Iwao, however, counting the number of syllables that could be missing from the folio reporting the story in question, show that the $D b a^{\prime}$ bzhed contains many more syllables than the missing section of the BL fragment. ${ }^{24}$ They thus suggest that what is missing are the names of the second and third ministers together with the words "you three ministers." It is clear therefore that Sang shi was not originally one of the ministers who interviewed Śāntarakșita. Although at this point only speculation is possible, it seems that, in the process of transcription of the narrative, redactors tried to associate Sang shi with the key figures of the gradualist school. In this way he could first be presented as someone with moderate feelings concerning the dispute between Moheyan and Kamalaśila, and then as a proponent of the gradualist school, until his name was displaced by that of Dpal dbyang. ${ }^{25}$

Some scholars have proposed that the exchange of Sang shi for Dpal dbyangs in the debate was caused by the fact that the identity of Sang shi throughout the text is unclear, and that sometimes he was identified with Dpal dbyangs. ${ }^{26}$ There is no doubt that a number of misidentifications occurred during the transmission of this text, which eventually led to the replacement of Sang shi with Dpal dbyangs. The source of the problem was the insertion of a certain Sang shi ta among the names of the first Tibetans who learned Sanskrit and took monastic vows. This

24 See Sam van Schaik and Kazushi Iwao, "Fragments of the "Testament of Ba' from Dunhuang," Journal of the American Royal Society 128, no 3 (2008): 483. On this point see also Chapter 3 in this volume. 25 It is also possible that Sang shi acted only as the translator and did not express his own opinion at the debate, but the present text does not give any evidence to support this turn of events.

26 See Wangdu and Diemberger, $d B a$ ' bzhed, 83, n. 318;
Sang shi ta -according to SBA 1961.1-2, SBA 1982.1-3 and several other later sources-took the ordained name Dpal dbyangs. Thus, when Sang shi was equated with Sang shi ta, Sang shi's ordained name also became Dpal dbyangs. The narrative concerning the establishment of the Tibetan samgha is reported in many chos 'byung and it is subject to a number of variations. Beside Sang shi ta, the identities of many other characters and their presence or absence in the narrative, varies from text to text. The number of lists reciting the names of the first ordained Tibetans increased to the point that some authors-unable to choose among so many different narratives-found it expedient to include more than one list in their histories. Although the Testimony of $\mathrm{Ba}$ is the locus classicus for this narrative, and many later chos 'byung drew their accounts from this tradition, it is equally true that later versions of the $S b a / R b a$ bzhed were informed by outside narratives. ${ }^{27}$ How much other sources were responsible for the final identification of Sang shi, Sang shi ta and Dpal dbyangs is difficult to determine. Yet, even if one could trace the source of this identification it would not necessarily mean that the same source would be responsible for the substitution of discussants in the debate. At present I shall mainly deal with what SBA 1961.1-2, SBA 1982.1-3, SBA 1980 and DBA' 2000 say concerning Sang shi/ Sang shi ta's identity. Table 5.3 below keeps track of the following discussion. To simplify a complex situation, I only look at the names that are of interest for Sang shi ta's identification, and thus this table cannot be used for any comparative study about the names of the first Tibetans who learned Sanskrit and/or took monastic vows. ${ }^{28}$ Everything added in curly brackets is found as gloss in the text.

SBA 1961.1-2 refers to a person named Sba Khri bzher sang shi ta, who learned Sanskrit, ${ }^{29}$ and to a 'Ba' Khri bzher sang shi ta, who became a monk. ${ }^{30}$ These two-despite the discrepancy in the clan name-are understood to be the same person.

SBA 1961.1-2's list of the first Tibetans who took monastic vows runs as follows: Sba Gsal snang, 'Ba' Khri zher sang shi ta, Vairocana, son of Pa gor Na 'dod, Ngan lam Rgyal ba mchog yangs, Sma A tsa ra Rin chen

27 On this point, see Leonard W.J. van der Kuijp, "Some Remarks on the Textual Transmission and Text of Bu ston Rin chen grub's Chos 'byung, a Chronicle of Buddhism in India and Tibet," Revue d'études Tibétaines, no. 25 (April 2013): 149-51.

28 For a more inclusive discussion, see van der Kuijp, "Some Remarks" (especially pp. 182-89) and Tucci, Buddhist Minor Texts II, 13-15.

29 SBA 1961.1-2, 50.3.

30 SBA 1961.1-2, 51.1-2. 
Table 5.3: Sang shi ta, Dpal dbyangs and Ratna's names in DBA' 2000, SBA 1961.1-2, SBA1982.1-3 and SBA 1980's quotation of the Rba bzhed che ba

\begin{tabular}{|c|c|c|c|c|}
\hline & DBA' 2000 & SBA 1961.1-2 & SBA 1982.1-3 & $\begin{array}{l}\text { SBA } 1980 \\
\text { Reporting large version } \\
\text { of the Testimony of } \mathrm{Ba}\end{array}$ \\
\hline $\begin{array}{l}\text { Among the Tibetans who } \\
\text { learned Sanskrit }\end{array}$ & $\begin{array}{l}\text { No Sang shi ta } \\
\text { Rad na son of Dba' Rma } \\
\text { gzigs. He was given the } \\
\text { name Rad na with his } \\
\text { ordination }\end{array}$ & $\begin{array}{l}\text { Sba Khri bzher sang } \\
\text { shi ta }\end{array}$ & $\begin{array}{l}\text { Ratna, son of Sba Rma } \\
\text { gzigs \{also known as Khri } \\
\text { bzher\}, was also known } \\
\text { as Sang shi ta son of Sba } \\
\text { Khri bzher }\end{array}$ & $\begin{array}{l}\text { Rba Khri gzigs Sangs shi } \\
\text { ta son of Rba Khri bzher }\end{array}$ \\
\hline $\begin{array}{l}\text { First Tibetan to become } \\
\text { a monk }\end{array}$ & $\begin{array}{l}\text { No Sang shi ta } \\
\text { Dba' Lha btsan: ordained } \\
\text { name Dpal dbyangs }\end{array}$ & $\begin{array}{l}\text { 'Ba' Khri gzigs becomes } \\
\text { known as 'Ba' Ratna }\end{array}$ & $\begin{array}{l}\text { Sba \{also known as Sang } \\
\text { shi ta\} Khri gzigs took } \\
\text { the ordained name Sba } \\
\text { Dpal dbyangs. He also } \\
\text { becomes known as Sba } \\
\text { Ratna }\end{array}$ & $\begin{array}{l}\text { Rba Khri gzigs took } \\
\text { the ordained name } \\
\text { Dpal dbyangs. He also } \\
\text { becomes known as Rba } \\
\text { Ratna }\end{array}$ \\
\hline $\begin{array}{l}\text { In the list of the ordained } \\
\text { men (sad mi) }\end{array}$ & $\begin{array}{l}\text { only two names are } \\
\text { given and none of them } \\
\text { is connected with Sang } \\
\text { shi ta }\end{array}$ & $\begin{array}{l}\text { Sba Khri bzher sang shi } \\
\text { ta: ordained name Dpal } \\
\text { dbyangs }\end{array}$ & Sba Khri bzher & $\begin{array}{l}\text { No Sang shi and no } \\
\text { Ratna }\end{array}$ \\
\hline $\begin{array}{l}\text { Kamalaśîla's disciples } \\
\text { (for a complete list see } \\
\text { Table } 5.2 \text { ) }\end{array}$ & $\begin{array}{l}\text { Dba' Dpal dbyangs } \\
\text { and } \\
\text { Dba' Rad na }\end{array}$ & $\begin{array}{l}\text { Dpal dbyangs } \\
\text { and } \\
\text { Ratna }\end{array}$ & $\begin{array}{l}\text { Sba Dpal dbyangs } \\
\text { and } \\
\text { Sba Ratna }\{\text { Ye shes } \\
\text { dbang po }\}\end{array}$ & $\begin{array}{l}\text { Rba Dpal dbyangs } \\
\text { and } \\
\text { Ye shes dbang po }\end{array}$ \\
\hline $\begin{array}{l}\text { Discussants at the } \\
\text { debate }\end{array}$ & $\begin{array}{l}\text { Sang shi and } \\
\text { Dpal dbyangs }\end{array}$ & $\begin{array}{l}\text { Sang shi and } \\
\text { Dpal dbyangs }\end{array}$ & $\begin{array}{l}\text { Dpal dbyangs and } \\
\text { Ye shes dbang po }\end{array}$ & $\begin{array}{l}\text { Dpal dbyangs and } \\
\text { Ye shes dbang po }\end{array}$ \\
\hline
\end{tabular}

mchog and La gsum Rgyal ba'i byang chub. ${ }^{31}$ At the end of the list, the text reports that they received the ordained names of Ye shes dbang po, Dpal dbyangs, and so forth (la sogs $p a$ ). Therefore, if the identification is one-to-one, Ye shes dbang po and Dpal dbyangs would be the ordained names of Sba Gsal snang and 'Ba'/Sba Khri bzher sang shi ta respectively. All the sources agree that Ye shes dbang po was the name of Dba' Gsal snang after ordination, thus it would make sense if Sang shi ta's ordained name was Dpal dbyangs. In this way, SBA 1961.1-2 equates Sba/'Ba' Khri bzher sang shi ta with Dpal dyangs. If the compiler of SBA 1961.1-2 understood this Sang shi ta to be none other than 'Ba' Sang shi, the son of the Chinese envoy, the identification Sang shi = Dpal dbyangs would be accomplished. Yet, SBA 1961.1-2 does not mistake Sang shi ta for Sang shi and-like the Dba' bzhed-has Sang shi and Dpal dbyangs as two different individuals speaking at the debate.

31 SBA 1961.1-2, 51.1-4.
SBA 1982.1-3, in its list of the Tibetans who learn Śāntarakșita's language, also has a Sang shi ta but he is not named 'Ba' Khri bzher sang shi ta as in SBA 1961.1-2. Instead it is said that Sba Khri bzher is the father of Sang shi ta, so that instead of one person (Sba Khri bzher sang shi ta) we have two: 'Ba' Khri bzher and his son, Sang shi ta. ${ }^{32}$ Here Sang shi ta is also identified with Ratna, who is said to be the son of Sba Rma gzigs. However, if Ratna and Sang shi ta were the same person, they could not be born from two different fathers. Thus, a note was added, in parentheses and in a smaller font, claiming that Sba Rma gzigs was also known as Khri bzher. In this way, Sba Khri bzher and Sba Rma gzigs become the same person in order to identify Sang shi ta with Ratna.

One cannot be surprised that the annotator decided to identify the two fathers. It is curious that the main text, while claiming Ratna and Sang shi to be the same person,

32 SBA 1982.1-3, 58.7-8 reads: sba rma gzigs \{khri bzher yang zer $\}$ kyi bu rat+Nar/ sba khri bzher gyi bu sang shi ta yang zer ba .... 
specified that they were the sons of two different fathers. As their names appear in a list, it would seem logical to speculate that in an earlier version the two names were distinct, and only later someone modified the text in order to identify them. ${ }^{33}$

Below, on the same page, the text states that a certain Sba Khri gzigs was the first Tibetan to be ordained and that his name as a monk was Sba Dpal dbyangs. The king was so happy about his ordination that he proclaimed him to be the jewel of Tibet and bestowed on him the name Ratna. Thus he came to be known as Sba Ratna. ${ }^{34}$ Another gloss informs us that this Sba Khri gzigs is none other than Sang shi ta. As previously noted, the text claims that the son of Sba Rma gzigs was a certain Sba Ratna, who was also named Sang shi ta. The annotator could not but assume that this Sba Ratna was the above-mentioned Ratna, son of Sba Rma gzigs and therefore Sang shi ta himself. Interestingly, SBA 1961.1-2 has a virtually identical passage, recognising 'Ba' Khri gzigs as the first Tibetan to be ordained-and uses almost the same words as SBA 1982.1-3-but Dpal dbyangs does not feature in it: 'Ba' Khri gzigs is only given the name Ratna by the king and no further identification takes place. ${ }^{35}$ Thus, although SBA 1961.1-2 still identifies Khri bzher sang shi ta with Dpal dbyangs, it draws a distinction between Sang shi ta/ Dpal dbyangs and 'Ba' Khri gzigs/ Ratna. SBA 1982.1-3, on the other hand, goes a step further and iden-

33 This impression is reinforced by the way the text was typed. Although the grammatical structure is clear, the names of Ratna and Sang shi are divided by a shad, giving the impression that once these were two separate individuals and that, instead of the terminative particle at the end of Ratna's name and yang zer ba de at the end of Sang shi's name, there were only two dang-s.

34 SBA 1982.1-3, 58.18-23.

35 Compare SBA 1982.1-3, 58.18-23 with SBA 1961.1-2, 50.13-16. SBA 1982.1-3 reads: btub bam sad par bya gsungs nas skad lobs pa tsho las thog mar bod la dad pa che ba'i sba \{sang shi ta yang zer\} khri gzigs dge slong byas ma thag tu mtshan sba dpal dbyangs su btags/ mngon par shes pa lnga dang ldan pas/btsan po dgyes te de'i zhabs spyi bor blangs te khyod bod kyi rin po che yin no zhes bka' bstsal nas mtshan kyang Sba rat+Na zhes btags te ... .

SBA 1961.1-2 reads: btub bam sad par bya gsung nas/ bod la dad pa che ba 'ba' khri gzigs dge slong byas ma thog tu mngon par shes pa dang ldan pas/btsan po dgyes te de'i zhabs spyi bor blang nas khyod bod kyi rat+na yin no ces bka' stsal bas ming kyang sba rat+na ces btags te ... .

Bu ston has an even shorter version of this episode, and calls Sba Khri gzigs, Bya Khri gzigs. It only says: mkhan po bo d+hi satwas byas nas tog mar bya khri gzigs rab tu phyung bas mngon shes lnga dang ldan par gyur te (Bu ston chos 'byung, 885:4). He is not exactly the author of this account however, as before he clearly says that he is reporting what he has heard from other sources. tifies Sang shi ta with Sba Ratna, Sba Dpal dbyangs and Sba Khri gzigs.

On the next page, SBA 1982.1-3 lists the Tibetans who received ordination after Ratna. ${ }^{36}$ It runs as follows: Sba Gsal snang, Sba Khri bzher, Vairocana, son of Pa gor Na 'dod, Ngan lam Rgyal ba mchog dbyangs, Rma A tsa ra Rin chen mchog, La gsum Rgyal ba'i byang chub. This-contrary to SBA 1961.1-2 and most other texts ${ }^{37}$-only reports one of the ordained names, Ye shes dbang po. Again if the reference is one-to-one, Ye shes dbang po is the name assigned to the first of the list: Sba Gsal snang. ${ }^{38}$ Thus, while SBA 1961.1-2 and SBA 1980 give also Dpal dbyangs as the ordained name of the second Tibetan in the list, SBA 1982.1-3 gives only one. It is logical to conclude that the name Dpal dbyangs was omitted because the text had already assigned it to Sba Khri gzigs Ratna/ Sang shi. As SBA 1961.1-2 does not contain the passage that gives to Sba Ratna the name Dpal dbyangs-and this story is not recounted in Bu ston-this was probably an interpolation. In fact, not only do most sources report two of the ordained names (Ye shes dbang po and Dpal dbyangs) and not just one, but Sba Khri bzher, when understood to be the father of Sang shi ta, as in this case, does not take monastic vows. Sba Khri bzher is listed as one of the Tibetans who became monks only when his name is one and the same with Sang shi ta's, i.e. when he is Sba Khri bzher sang shi ta.

These interpolations created inconsistencies that the person who wrote the annotations-probably Mgon po rgyal mtshan (on whom, see Chapter 1 above)-tried to smooth out. He did so by adding glosses that kept track of the different names that were assigned to each character, and also sometimes by writing longer annotations that explained difficult points. SBA 1982.1-3 already has Dpal dbyangs and Ye shes dbang po speaking at the debate. It also identifies Sba Ratna with Sang shi ta and both with Dpal dbyangs. Thus, it is possible that even before glosses were added, the equation Sang shi = Sang shi ta = Dpal dbyangs had already taken place. However, the main text does not explicitly say that the Chinese Sang shi is Sba Sang shi ta. It is the annotator that, drawing his own conclusions from the text, in a longer note declares

36 SBA 1982.1-3, 59.1-5.

37 e. g. SBA 1980, 351:3-4; and Bu ston chos 'byung, 885:5.

38 SBA 1982.1-3, 59.1-6: sad cig gsungs nas sba gsal snang dang/sba khri bzher dang/ pa gor na 'dod \{he 'dod kyang zer\} kyi bu bai ro tsa na dang/ ngan lam rgyal ba mchog dbyangs dang/ rma a tsa ra rin chen mchog dang/ la gsum rgyal ba'i byang chub dang drug dge slong byas te/ ming yang ye shes dbang po dang/ de la sogs par btags nas sad mi drug rab tu byung ngo. 
that Sang shi ta is a Chinese name and thus implicitly identifies the two. This annotation reads: ${ }^{39}$

Sba Dpal dbyangs was called Sang shi ta in Chinese; some say that Sang shi ta was the son of Khri bzher. Sba Gsal snang was [Ye shes dbang po's] name when a layman, after he had developed an enlightened frame of mind and took monastic vows, the preceptor Bodhisatva named him Ye shes dbang po .... ${ }^{40}$

Thus, it is certain that the annotator at least understood Dpal dbyangs and Sang shi to be interchangeable, and also that he made a one-to one association between the names in the list of ordained monks and the examples of ordination names given after it (Sba Gsal snang = Ye shes dbang po). ${ }^{41}$

The idea that originally there was no identification of Sba Ratna with Sang shi and Dpal dbyangs seems also to find some corroboration in the subsequent narrative. In SBA 1982.1-3's account of Heshang Moheyan's arrival in Tibet, it is said that at that time only a few Tibetans continued studying with Sāntarakșita. Three names are given: Sba Ratna, Vairocana and Dpal dbyangs..$^{42}$ Thus, here the main text distinguishes between Sba Ratna and Dpal dbyangs. However, the annotator realised that if Sba Ratna was Dpal dbyangs he could not be named twice in the list and so added "Ye shes dbang po" next to Sba Ratna's name in order to identify the two. ${ }^{43}$ This further identification complicated matters rather than simplifying them, being in stark contrast with the narrative of the main text, which clearly states that Ye shes dbang po was the ordained name of Sba Gsal snang. Moreover, given the previous identification of Sba Ratna with Dpal dbyangs it is evident that the scenario here proposed by the anno-

39 SBA 1982.1-3, 59.6-8. van der Kuijp, “Some Remarks," 158-59 notes this gloss and translates it. I have reformulated his translation in order to emphasise that, at least on this occasion, the annotator seems to have distinguished between Dpal dbyangs and Gsal snang. However, the sentence is open to interpretation. For the Tibetan, see the footnote below.

40 SBA 1982.1-3, 59.6-10: sba dpal dbyangs la rgya nag skad sang shi ta zer/ la la khri bzher gyi bu sang shi ta zer/ sba gsal snang skya ba’i dus ming/ de nas sems bskyed zhus nas dang rab tu byung nas ming ye shes dbang por slob dpon bod+hi satwas btags ... .

41 However, the remark "some (la la) allege that Sang shi ta was the son of Khri bzher" is baffling because this is exactly how SBA 1982.1-3 presents these two people. van der Kuijp noted that the Dba' bzhed contains a similar account concerning the time of the sad mi's ordination; van der Kuijp, “Some Remarks,” 159, n. 89. In the Dba' bzhed, this passage is found at DBA' 2000, 17r:5-17v:5.

42 SBA 1982.1-3, 64.15-18.

43 SBA 1982.1-3, 64.16-17: sba rat+Na \{ye shes dbang po\} dang/ bai+' ro tsa na dang/ dpal dbyangs la sogs nyung shas gcig bo d+hi satwa'i chos slob. tator is unfeasible: how could Sba Ratna/ Sang shi/ Dpal dbyangs and Ye shes dbang po be the same person and be consistently treated as two different men in the main narrative? A plausible reason why the annotator might have identified Sba Ratna with Ye shes dbang po at this point is because Dpal dbyangs and Ye shes dbang po were already the two people who, according to the main text, spoke at the debate in favour of the gradual approach. It was thus logical to find them among the students who were loyal to Sāntarakșita.

We know that SBA 1982.1-3 was compiled by collating three different manuscripts, but it is not possible-in its present typed format-to distinguish if one, two or more hands wrote the annotations or even if these two sections (the ordained men and the Heshang's arrival in Tibet until the end of the debate) were drawn from two different sources that contained two different sets of annotations. Yet, before drawing any conclusion from this one needs to address a problem that lies even deeper than the appended annotations. This is the fact that earlier annotations/interpolations were included into what is now the main text of SBA 1982.1-3. The section that identifies Ratna with Sang shi ta, but attributes to them different fathers, and the section that identifies Sba Ratna with Dpal dbyangs, which is not found in SBA 1961.1-2, appear in the main body of SBA 1982.1-3 but they do not fit with the overall narrative. Thus we see (at least) two layers of annotations/ interpolations, one hidden and one overt. ${ }^{44}$

It is probable that the 'original' 'ordained men' (sad mi) section in SBA 1982.1-3 did not identify Sba Ratna with Sang shi, and thus presented them as the sons of two different fathers: Sba Rma gzigs and Sba Khri bzher. Like in SBA 1961.1-2, Sba Ratna's name as a layman was Sba Khri gzigs; he was the first Tibetan who received ordination. It is also possible that this earlier recension of SBA 1982.1-3, after listing the Tibetans who took monastic vows after Ratna, provided two (rather than one) ordained names the sad mi received, i.e. Ye shes dbang po and Dpal dbyangs. If this were the case, Dpal dbyangs would be the ordained name of the second name in the list Sba Khri bzher (Sang shi's father) who is the second in the list. However, this sounds improbable. It is more likely that the text, at that stage, instead of Sba Khri bzher, had either "Sba Khri bzher kyi bu Sang shi ta" or even "Sba Khri bzher sang shi ta"; thus recognising Dpal dbyangs as the ordained name of Sang shi ta but not linking these two names to those of Sba Ratna/ Sba Khri gzigs. When Moheyan came to Tibet three people

44 The hands that wrote these two layers of annotations could also easily be more than two. 
remained faithful to the gradualist side: Sba Ratna, Vairocana and Sba Dpal dbyangs, and these three are exactly the same people who are listed as Kamalaśilla's disciples at the beginning of the debate. According to this 'earlier' reading, this situation presents no difficulties: Sba Ratna is not Dpal dbyangs/ Sang shi ta and thus the narration proceeds smoothly. Dpal dbyangs, as one of the ordained men and loyal to Śāntarakșita and Kamalaśîla, naturally speaks in favour of the gradualist side at the debate.

At a later stage, interpolations found their way into the main text: Sba Khri gzigs Ratna was identified with Sang shi ta and then with Dpal dbyangs. Dpal dbyangs was then omitted from the list of ordained names because Ratna/ Sang shi ta had already been identified with him. Yet, the section concerning Śāntarakșita's three faithful students-Sba Ratna, Vairocana and Dpal dbyangs-was left unchanged although problematic since at that point Ratna and Dpal dbyangs had already been equated. ${ }^{45}$ The same thing happened for the list of Kamalaśila’s disciples, where again these two were written down as two different individuals. Hence, we can think of at least two scenarios: 1. the copies of the Testimony that the editor assembled did not agree concerning these people's identities and the editor simply reported them as he found them trying to reconcile them through his annotations; 2 . some of the annotations do not belong to the editor but were found in the manuscript he copied and he left them as glosses to the main text.

As the number of texts that discussed the early spread of the dharma increased, confusion about the identity of Sang shi (and several other characters of the narrative) became greater. ${ }^{46}$ For example, Mkhas pa Lde'u in the "royal genealogies" section of his chos 'byung writes that a Sba Khri bzher sang shi ta introduced three texts from China (i. e. Las kyi sgrib pa rgyun gcod pa, Sa lu ljang pa and $R$ do rje gcod). ${ }^{47}$ The connection of this Sang shi ta with China seems to imply that Sang shi ta and Sang shi were one person.

$45 \mathrm{Bu}$ ston, who does not identify Sba Ratna with Dpal dbyangs, writes that the Tibetans who continued studying with Sāntarakșita after Moheyan's arrival were Dpal dbyangs and Bha Ratna, but omits Vairocana (Bu ston chos 'byung, 887:2).

46 Tucci attributed the addition of two people in Bu ston's list of the first Tibetans to be tried for ordination to political reasons; Tucci, Minor Buddhist Texts II, 16. van der Kuijp demonstrated that these additions were already attested in older texts and there was therefore no political motivation behind it. See van der Kuijp, "Some Remarks," 174-189.

47 Mkhas pa lde'us mdzad pa’i rgya bod kyi chos 'byung rgyas pa in Rgya bod kyi chos 'byung pa (Lhasa: Bod ljongs mi dmangs dpe skrun khang, 1987), 302:7-8.
At the time Dpa' bo Gtsug lag phreng ba wrote, in the sixteenth century, the situation was such that he felt these issues had to be addressed. In SBA 1980 he quoted at length from an "extended version of the Rba bzhed." 48 The long citation from this manuscript is very similar to both SBA 1961.1-2 and SBA 1982.1-3, but there is no doubt that the manuscript Gtsug lag phreng ba was consulting was, in this case, closer to SBA 1982.1-3.49 This quotation is once again the famous passage concerning the Tibetans who learned Sanskrit, the first who took monastic vows and the subsequent list of sad mi. The quotation is faithful to SBA 1982.1-3 in all salient points and, in short, it presents Sba Khri gzigs sang shi ta as the son of Rba Khri bzher and identifies him with Dpal dbyangs and Rba Ratna. The only difference of any consequence is that Sba/'Ba' Khri bzher is omitted in SBA 1980's list of sad mi.

Gtsug lag phreng ba's comments follow the quotation. According to him, the report of these events is corrupted..$^{50}$ His first example of such corruption is that someone (including the extended version of the Sba bzhed he had just cited) claimed that Sang shi, the Chinese dancing child, was named Rba Sang shi and that someone even said that he was one and the same as Rba Ratna, the son of Rba Khri bzher. Gtsug lag phreng ba rightly remarks that, as Sang shi was the son of a Chinese envoy, he could

48 SBA 1980, 355:3-356:3, which is then followed by Gtsug lag phreng ba's comment.

49 However, Gtsug lag phreng ba had access to more than one version of the Sba/Rba bzhed. This can also be easily deduced from the fact that Gtsug lag phreng ba previously quotes from a Rba bzhed 'bring po, SBA 1980, 354:6. Yet, the following quotation from the large $R b a$ bzhed is closer in five points to SBA 1982.1-3: One is that there is a section reporting the invitation of twelve Sarvāstivāda monks to Tibet, which in SBA 1961.1-2 comes later in the narrative than in SBA 1982.1-3 and Gtsug lag phreng ba has it at the same point as SBA 1982.1-3. The second is that he identifies Khri bzher as the father of Sang shi ta and not Sang shi ta himself as SBA 1961.1-2 does. The third point concerns the already discussed passage where the first monk Ratna is identified with Dpal dbyangs. As discussed above, SBA 1961.1-2 does not contain this passage, while Gtsug lag phreng ba includes it, even if only to criticise it later as spurious. The fourth point is that, because Gtsug lag phreng ba's quotation like SBA 1982.1-3 identifies Dpal dbyangs with Ratna with Gtsug lag phreng ba, Dpal dbyangs is then omitted from the list of ordained names that the sad mi received. Fifth, both SBA 1982.1-3 (58.21-23) and SBA 1980 (356:12 ), in reporting the story of how Ratna got his name from the king, have the king say that Khri gzigs is the "rin po che" of Tibet and so he was given the name "Ratna” In SBA 1961.1-2 (50.14-15), instead, the shift from the Tibetan word and its Sanskrit equivalent to the name is lost as both instances are documented as "Ratna." Except for these five points, however, SBA 1961.1-2 and SBA 1982.1-3 are more closely related to each other than to SBA 1980.

50 SBA 1980, 356:4 (for the Tibetan, see the footnote below). 
not be a descendant of the Rba' clan. He also points out that Rba Khri gzigs could not be named Bya Khri gzigs, as many people spelled his name. ${ }^{51}$ He then shows how the names of certain individuals in the list of sad mi had been modified and how sometimes people were added to it, referring more specifically to some mistakes that he had found in Bu ston's chos 'byung. ${ }^{52}$ Later on, he also claims that there was a certain amount of confusion about Sba Ratna's identity, and that some believed him to be Ye shes dbang po. ${ }^{53} \mathrm{Bu}$ ston does not seem to connect these two characters, and although Gtsug lag phreng ba might have referred to what he found written in other texts, the identification of Sba Ratna with Ye shes dbang po reminds one of the annotation in SBA 1982.1-3. Thus, it is possible that the gloss next to Sba Ratna's name was there by the middle of the sixteenth century, or even earlier.

Although Gtsug lag phreng ba was aware that the identification of Sang shi with Sang shi ta was wrong, in the version of the debate he had at his disposal, Dpal dbyangs already takes Sang shi's place. ${ }^{54}$ SBA 1980 follows SBA 1982.1-3 in this, and starts what was Sang shi's speech with the words: "khyed rgya'i bzhed pa ltar na ... ." It is possible that in the sixteenth century, sources mostly agreed that these two were the interlocutors at the debate and Sang shi's speech had already been established to be on the gradualist side.

The $D b a$ ' bzhed narrative of these events is much shorter and simplified. Interestingly, as in the later redaction of SBA 1982.1-3 the first monk to be ordained takes the name Dba' Dpal dbyangs. The Dba' bzhed, however, says that this person's name before ordination was Dba' Lha btsan and not Ratna or Khri gzigs. ${ }^{55}$ Two folios below, the Dba' bzhed reports that Dba' Gsal snang took monastic vows and the name Ye shes dbang po was bestowed on

51 On this see van der Kuijp "Some Remarks," 171; SBA 1980, 356:4-5: 'di dag du yi ge ma dag pa 'phel ba las sngar gyi rgya phrug gar mkhan de la yang rba sang shi zhes bris pa sogs snang ya+ng rba rat+na ni rba khri bzher gyi bur bshad la rgya phrug sang shi ni rgya nag gi pho nya'i bu yin pas rba'i rus su mi 'ong la/ yang bya khri gzigs ces bris pa du ma yod kyang yi ge nyams pa ste rus de gnyis kyi gzhi mthun mi srid to.

52 Gtsug lag phreng ba in this case does not blame Bu ston for the mistakes in the text; he rather hypothesises that these were added at the time of carving the woodblocks for the printing of the chos 'byung. SBA 1980, 356:6-7 reads: bu ston chos byung du'ang par brko dus zhus dag pas nyams pa yin nam ... . This section has been already analysed by van der Kuijp, see “Some Remarks," 172-174. See also Tucci, Minor Buddhist Texts II, 20-21.

53 SBA 1980, 357:2. rba rat+na'i ming ye shes dbang po yin pa 'dra ba sogs nag nog che bar snang ngo. See also van der Kuijp, "Some Remarks," 172-173.

54 SBA 1980, 384:6.

55 DBA' 2000, 14v:7-15r:1. him..$^{56}$ Later, the $D b a^{\prime}$ bzhed relates that among the people who were taught Sanskrit, such as Mchims legs gzigs etc., only some eventually learned it. These were: Śākyaprabha son of Mchims Anu, Vairocana son of Pa 'or Na 'dod, Rad na (i. e. Ratna) son of Dba' Rma gzigs, Lha bu son of Zhang Nya bzang, Bse btsan and Shud pu Khong slebs. Finally, it remarks that: "The son of Dba' Rma gzigs was given the name Rad na (i.e Ratna) upon his ordination." ${ }^{57}$ The Testimony of $B a$ versions therefore have many points in common: with some spelling variation, Sākyaprabha, Vairocana, Rad na and Shud pu khing slebs also appear in SBA 1982.1-3 and SBA 1961.1-2. SBA 1982.1-3 also agrees with the $D b a$ ' bzhed in reporting that Ratna's father was named Dba' Rma gzigs; and in relating that Mchims Legs bzang (i.e. $D b a$ ' bzhed's Mchims Legs legs gzigs) did not learn Sanskrit. Yet, the $D b a^{\prime}$ bzhed mentions no Sang shi ta, no Sba Khri bzher and does not identify Dpal dbyangs either with Ratna or Sang shi ta/ Khri gzigs.

It is unclear on which sources SBA 1961.1-2 and SBA 1982.1-3 drew for depicting Sang shi ta and all the other characters that do not feature in the $\mathrm{Dba}$ ' bzhed. Considering that SBA 1961.1-2 does not replace Sang shi with Dpal dbyangs-although Sang shi ta features in the narrative of the sad mi-we can conclude that originally the inclusion of Sang shi ta in the Testimony of Ba had nothing to do with the debate. The identification happened later in the history of transmission of SBA 1982.1-3.

One question remains: why all this confusion about Sang shi's affiliation with the Chinese side? Sang shi plays an important role in the establishment of Buddhism in Tibet..$^{58}$ In the $D b a^{\prime}$ bzhed, he is one of the ministers who goes to China to meet master Kim and the Chinese emperor. In the later Testimony of $B a$ tradition, he is the son of a Chinese envoy and he is also the person who introduces Buddhism to king Khri Srong lde btsan. Throughout the narratives he is crucial to the king's decision to adopt Buddhism and he carries out tasks that are necessary to achieve this end. Sang shi could not be on the side of the

\section{DBA' 2000, 17r:6.}

57 DBA' 2000, 17r:6-17v:3. It is interesting that the monk who acted as a preceptor for the second set of ordinations in the $\mathrm{Dba}^{\prime} \mathrm{bzhed}$ is a certain Dba' Rin po che, which seems to refer to Dba' Ratna who is introduced two lines above. This recalls SBA 1982.1-3 and SBA 1980's double rendering of his name in Sanskrit and Tibetan (see footnote 48, above). In this instance, SBA 1961.1-2, 51.10-11 refers to this person as "Sba Rat+na" rather than "Rin po che."

58 See DBA' 2000, 25r:1-3: "Whereas the dharma could not be established during the reign of the five previous kings, the devaputra Khri Srong lde btsan, Ācārya Bodhisatva, Dba' Ye Shes dbang po and 'Ba' Sang shi-those four-established seats for the triple gem (and) the noble holy dharma was propagated widely in the region of Tibet." 
defeated Chinese, so he could only take the stance of the winners in the debate. Thus, it is possible that successive compilers of the Testimony of $\mathrm{Ba}$ progressively distanced Sang shi from the Chinese side, which in some textual traditions somehow resulted in the replacement of Sang shi with Ye shes dbang po.

\section{Dpal dbyangs and the Samdhinirmocana sūtra}

After Sang shi's speech, Dpal dbyangs intervenes by saying that the gradual and instantaneous approaches should be spoken of distinctly, thus replying to Sang shi's last sentence. Then, after having emphasized this point through metaphors, he starts with an exposition of the stages of the bodhisatva path (23r:3-23v:6). This section is extracted from the Samdhinirmocana sūtra-the text that Heshang Moheyan and his followers had dismissed during their preparation for the debate in preference for the Shes $r a b$ 'bum. ${ }^{59}$ At the end of this quotation Dpal dbyangs attacks the instantaneous approach directly, asserting that they lack scriptural knowledge and that a person who follows their path is unable to help himself, let alone others. As Moheyan and his followers are unable to answer Dpal dbyangs, the gradualists win the debate by quoting the very text the Chinese monk had rejected.

The quotation from the Samdhinirmocana sūtra is curtailed in the following versions of the Testimony. Only a few sentences remain of the quotation found in the $D b a$, bzhed (folio 23r line 4 to folio 23v, line 6). This makes the link between the introduction of the debate and the debate itself less evident. The reason for shortening the Samdhinirmocana sūtra's quotation in the later versions of the Testimony of $B a$ is unclear. ${ }^{60}$ We can only assume that the importance given to the philosophical dispute decreased as time passed.

59 See Mdo sde dgongs pa nges 'grel (Ārya-saṃdhi-nirmocana-sūtra) in $B k a$ ' 'gyur (Sde dge: Sde dge par khang chen mo, 1733), vol. 49. The quotation from this sūtra runs from pp. 79:6 to 81:4. Although the quotation is mostly linear and the two works are very close in wording, it should be noted that the person who wrote this section of the Dba' bzhed did not copy it completely from the sūtra. The Samdhinirmocana sütra uses a very repetitive structure when writing about the ten bodhisatva stages, which the writer of the $D b a$ ' bzhed curtailed probably for the sake of space. In his Bhāvanākrama, Kamalaśîla often quotes the Samdhinirmocana sūtra, however, this specific quotation does not feature in his text.

60 For connections between the Saṃdhinirmocana sūtra and Atiśa, the Bka' dam pas and later Tsong kha pa see Alex Wayman, "Doctrinal Disputes.”

\section{Final Remarks}

This overview shows that the debate-like the rest of the Testimony and the majority of Tibetan Buddhist texts-was created by combining a variety of sources and that much thought was given to the assemblage of the units. Each string that we find in the Introduction to the debate is tied to a section of the debate itself. Sāntarakșita's prophecy is picked up by Sang shi's view of school formation. The Shes rab 'bum studied by the instantaneous party is then quoted in Sang shi's speech. The Sampdhinirmocana sūtra, dismissed by the instantaneous party, is then picked up by Dpal dbyangs who wins the debate by quoting from it.

As the transcription of the $D b a^{\prime}$ bzhed in Part Two of this volume shows, the scribe does not seem much interested in the philosophical dispute. That he was copying the debate from a parent manuscript is evident from the number of mistakes that he makes in transcribing the text. Twice he copied the wrong sentence because the passage that he was supposed to write started with the same word as the next sentence. ${ }^{61}$ Thus, we can conclude that he did not know the source by heart and that he was not writing under dictation. Therefore, although it seems likely that the $D b a^{\prime}$ bzhed compiler had some sort of agency over the text, by adding bits and pieces he found useful into the main narrative, it is improbable that he assembled the debate narrative. He simply copied it.

David Seyfort Ruegg identified one interesting clue about the date of the compilation of the debate. ${ }^{62}$ Since the third of the three Mâdhyamika schools mentioned in Sang shi's speech originated in Tibet through the work of Pa tshab Nyi ma grags-who was born around 1055the text could not have been written before the eleventh or twelfth century. As the writer of the manuscript of the Dba' bzhed does not seem to be the person who collated the text part, we may conclude that the manuscript he was drawing from (or even a progenitor of the manuscript he was drawing from) was probably written around or after the eleventh or twelfth century. The original narrative must have looked similar to what we read in the $D b a^{\text {, }}$ bzhed today although some points might have been added or cut during the transmission and copying of the text after the twelfth century.

61 DBA' 2000, 19v:6 and 21r:7. 62 Ruegg, Buddha-Nature, 80. 